\title{
Revisiting African Traditional Education to Promote Peace through Education in Africa
}

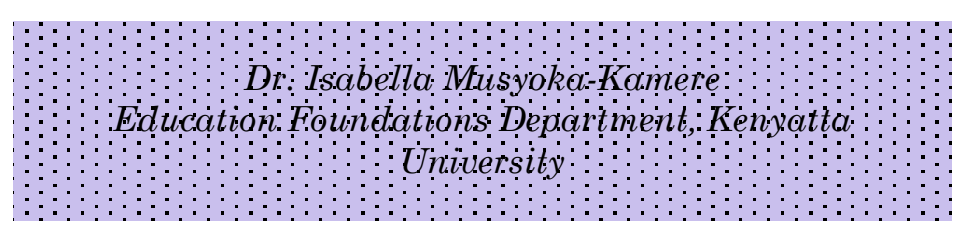

\begin{abstract}
African traditional values are the principles, standards and qualities, which Africans traditionally held dear for perpetuation of culture and society. They are the values that guided human action towards a common good. There are certain things that Africans found intrinsically valuable, that gave them a distinct cultural personality and enabled them to contribute to knowledge and history. Some of these include the sense of community life, sacredness of life and respect for authority and elders. These values of African traditional education can be revisited to infuse peace and unity in today's fragmenting society. Peace here is taken to mean the non-violent, nonexploitative, cohesive, tolerant and united co-existence between people and respect for the social environment. This paper will document the dominant African cultural values and attempt to assess the contribution of these values to the promotion of peace in modern times. This is a library-based research, which involves a desk review of
\end{abstract}


articles, documents and internet sources to draw facts and use the information to provide suggestions for promoting peace. It will try to bring out the salient values of African culture and see how these can be adapted to today's world to enhance peaceful co-existence and thus lead to change in public consciousness and habits to improve the quality of life. The findings of the study will highlight viable options for African societies to come out of their cultural quagmire and suggest ways of preserving values that lead to national cohesion and development.

\section{Introduction}

Education is an essential aspect of human development and a major contributor to sustainable development. It is the single most important means for empowerment and sustained wellbeing of societies and nations as a whole. It brings about changes in knowledge, values, behaviours, and lifestyles required to achieve sustainability and stability within and among countries and to ensure democracy, human security, and peace (Bajaj 2009). Education equips individuals with knowledge, skills and a change in attitudes that enhance productivity of both the individual and the nation. Hence, education should be dynamic to envisage a 
world where all benefit from it by learning the lifestyles, behaviours and values that are necessary to create a sustainable future. It must cultivate principles that develop economic, social, political, environmental and pacific concerns of human existence as a whole.

Education is one of the oldest means by which societies transmitted their culture from one generation to another to preserve, maintain and sustain societal equilibrium. Through it, societies have been able to prepare their youth to be functional members. Hence, a society's wellbeing and future, largely, depends on the quality of the education of its members. African traditional education, which is also called African indigenous education, aimed at socializing the youth to fit into the society and be fully functional members of the community (Okoro, 2010).

This education had two intertwined dimensions. It was both physical and moral, and incorporated ideas of learning a skill or vocation, social and cultural values, principles, ideals, standards, qualities and norms that Africans traditionally held dear for the perpetuation of culture and the society. Ingrained in this education were social values such 
as honesty, respect for rights and property of others, dignity of self, hard work and productivity, selfreliance and collective responsibility. In other words, social values and social order were the epicenter of this education, which was based on the philosophy of productivity and functionalism (Ocitti, 1973; Okoro, 2010).

African traditional education was a lifelong process, from birth to death and though it varied from society to society, it was similar in that it prepared the youth for life. It dealt with all aspects of life: social, political, religious and economic and was passed on by word of mouth and through practical demonstration, apprenticeship or example from one generation to another (Ocitti, 1973). It was progressive, gradual and practical and was about life and its experiences. It targeted at molding character and developing the moral values of the youth, while inculcating a sense of social responsibility within them; developing their physical aptitudes, intellect and instilling in them values that guide human action towards society's common good. It was characterized by its collective and social nature since it prepared the youth not just to be functional individuals but functional within the whole; to build a progressive, cohesive and peaceful 
society. Indigenous education system helps individuals and the society in general develop an awareness and understanding of certain specific modes of behavior that are viewed as crucial in the formation of a sane and civil society (Mosha, 2000).

Peace is often defined in relation to war to mean the converse of war or the absence of it. However, a more tranquil view of it is the presence of a serene, non-exploitative social structure, where justice and human rights prevail. The existence of peace leads to the wellbeing of the society, and consequently enhances productivity and leads to its development. Peace would therefore be desired by any forward looking and progressive-conscious society. Conforini (2006) presents Professor Gultang Johan's view of peace as a social condition in which exploitation and overt violence have been eliminated, as well as eradication and elimination of structural violence. Among many societies, peace is viewed as security. The lack of peace can take the form of oppressive domination, imposing of values and views and obstructing or suppressing the ideas, values and opinions of others. This paper looks at peace in its wholesome state, which is the lack of war, and the presence of unity, solidarity, tolerance and respect for people, institutions, the environment and social responsibility. 
Peace is the desired state of all human societies, first as the absence of war and then in its ideal state as non-exploitative, just and humane state. As earlier, mentioned, education is the main avenue, through which values are passed on from generation to generation and the quality of education determines what the society becomes. This paper will analyze how African traditional education was used to maintain peace in the society and how it can be revisited to bring the desired peace in modern day Africa.

\section{African Traditional Values and Education}

There are certain things that Africans found intrinsically valuable, that gave them a distinct cultural personality, enabled them to contribute to knowledge and history, enhanced their development and facilitated their total wellbeing Some of these include a sense of community life, the sacredness of life, family, respect for authority and elders, the importance of language and the perpetuation of culture; the spirit of being functional within the society and the conservation of the environment (Okolo n.d.). These aspects were entwined in the aims of African traditional education or the Africans' complete lifestyle. 
Most African traditional education was passed on orally, though the youth were also taught through apprenticeship whereby they imitated their elders in carrying out certain chores or in learning a trade. Apprenticeship involved observation, instruction and imitation with guidance (Sifuna D.N D., Chege F., Oanda, I., 2006). The aim of this traditional education was to transmit religion, knowledge, skills, values and culture from one generation to another. The essence of this was to pass on the wisdom, economic activity and knowledge of the family, clan and ethnic group from one generation to another. This process ensured continuity, understanding that the future of the tribe lay in the perpetuation of ethnic institutions, laws, language and values which would be handed down from generation to generation.

African traditional education emphasized the preservation of culture, the environment and the values of the society (Otiende, Wamahiu, S.P, Karugu, A.M. 1992: Bogonko, 1992). Its goal was to adapt the youth to their physical environment, which, was crucial for their survival and that of their community, by equipping the youth with skills, values and knowledge that enabled them to use and conserve their environment for future use 
and for generations to come. Its focal objective was to teach the youth communalism and collective responsibility for the common good of the tribe as a whole and to be as self-reliant as possible in order to be functional members of the society. The ultimate objective of traditional African education was to bring up an all-round youth who would contribute to the common good, growth and well-being of his/her society (Otiende J.E et. al, 1992; Mosha, 2000). Society invariably looked down on people who did not take up their roles as expected and those who were deemed lazy.

Similarly, African traditional education was important in the promotion of a culture of peace. It taught values and attitudes that promoted peace such as the value of solidarity, respect, tolerance, an appreciation of diversity, respect for the environment and social responsibility. It cherished communalism, whereby the value of an individual was seen in relation to the community. Peaceful living and co-existence was therefore the desired ultimate objective. 


\section{The Individual, the Community and Peaceful Coexistence}

Africans were intrinsically social. An individual was not recognized unless they belonged to the 'whole'. This message was carried in all aspects of life of traditional African societies. Undoubtedly, African folklore is rich in value of community living. Africans used language, legends, myths and stories, song and dance and all possible opportunities to advance the importance of the community. A popular African proverb cautions, "Go the way many people go: if you go alone you will have reason to lament" (African Cultural Values n.d.). This proverb is strongly supported by the words of Mbiti (1989) that "I am because we are; therefore since we are, I am”. Therefore, outside the community the individual was exposed, susceptible and worthless.

The value of community life in the traditional African context is seen in the sense of security that it provides. Undeniably, the society was regarded as the custodian of the individual and within it; the individual was protected and shielded from all harm including effects of poverty, hunger or other calamity (Ejizu, n.d). During times of need, members of the society assembled to collectively assist the individual and cushion him/her 
from want. Indeed communal activity was the ideal lifestyle and practice. This is exemplified in the African use of language such as in the Congolese saying, "A single bracelet does not jingle"; Akamba of Kenya saying, "One finger cannot kill a louse" and among the Bondei of Tanzania, "Sticks in a bundle are unbreakable". All these sayings echo the strength of a unified community. They affirm the common African saying that "A man outside his clan is like a grasshopper which has lost its wings" (Squidoo n.d), helpless, exposed and vulnerable. Consequently African traditional education taught the youth to respect relationships, value harmonious living and see the good of the whole community above that of self.

Ifeanyi Menkiti (n.d.), writing on the place of an individual in the community observes that the reality of the community takes precedence over the reality of the individual, and that it is in the rootedness of an ongoing community that the individual sees himself/herself as man or woman. Hence, the biological make up of a person is not what gives them self-identity, but their entrenchment in community. The personhood of an individual is not attained simply because one is born of a human seed, but because they are incorporated into a commu- 
nity. Unless this is so, one remains a 'mere dangler' with no identity. Thus, the full personhood of an individual is not at the beginning of life, but is attained as one is socialized into the society.

Being socialized into the community, leads to peaceful co-existence whereby the values and visions of others are respected, without suppressing the views, values and opinions of others (Otiende et.al1992; Bogonko 1992). A Senegalese viewpoint on peace sees it as emanating from healthy social relationships in that "there can be no peace without understanding" (Squidoo, n.d.). Thus, peace was the ultimate in African societies, in that the value, respect and sacredness of human life and peace were held dear across all African societies.

An African ethic or humanist philosophy, Ubuntu, which is believed to have originated from the Bantu languages of Africa, describes the innate humane, respectful and compassionate nature of humankind. It is a worldview that focuses on people's allegiances and relations with each other. It sees a person from the eyes of others and not as mere objects or individuals. In Malawi, this philosophy is called $u M u n t h u$, and proffers that individuals, on their own, are as good as animals of the 
wild; but find value within a community. Among the Kitara speaking people of Western Uganda and Northern Tanzania, this philosophy is known as obuntu and refers to the human characteristics of generosity, consideration and humaneness towards other members of the community. A similar view is upheld in Kinyarwanda and Kirundi, the national languages for Rwanda and Burundi respectively (Ubuntu Philosophy n.d.).

In Kiswahili, a language spoken throughout the coast of East Africa, Tanzania and most of Kenya, this philosophy is carried in the word $u t u$, which means humanness and is derived from the word $m t u$ meaning person. It is a concept, which condemns acts and deeds that seem unfair towards others even in the slightest way. The Bantu speakers of East Africa, who are believed to have originated from the Congo basin in pre-colonial times, were mainly governed by the philosophy of utu, which meant that everything was to be done for the benefit of the whole community. This philosophy describes the act of being humane to other human beings and to nature in general (Ubuntu Philosophy, n.d.). The utu concept embodies a nonexploitative, non-egoistic and non-idiosyncratic facet of peace. 
In traditional African societies, tolerance and respect for differences was encouraged. This was because African communities acknowledged that though people have differences, they could still live in harmony. The common African proverb, "Milk and honey have different colours but they share the same house peacefully" (Squidoo, n.d.) affirms this view. Individual differences, personal abilities and professions were respected and seen not as differences, but as strengths that bring in variety into the society.

In encouraging community living and shunning individualism, African traditional education discouraged disunity and war and encouraged peace through concern for each other. It socialized its youth to see themselves as part of the whole without which they do not exist. Each person was seen as supporting or holding the community together and was likened to the three stones of the traditional cooking stove where without one, the pot cannot stand. Thus, collectively individuals were bricks of the pillar that held and supported the individual. 


\section{Promoting Peace in the Modern World using Values of African Traditional Education}

Education is important in the promotion of a culture of peace. Through it, one can teach values and attitudes that promote peace such as the value of respect, tolerance and appreciation of diversity, care and concern for the environment and global responsibility. Most of Africa today is ravaged by war, poor governance, individualism and mismanagement of social structures. Furthermore, disorder leading to loss of life, poverty, disunity, the breakdown of the social fabric that held people together and the lack of peace, which has often led to a near collapse of social structures, are common in Africa today. People are intolerant and suspicious of each other and are divided along tribal, ethnic, political, social, religious and other divides. Peaceful coexistence and concern for each other is fading, giving way to an egoistic, idiosyncratic, fragmented society characterized by suspicion, greed, disharmony and exploitation.

Peaceful and harmonious living is threatened by a shortage of resources, ethnic and religious differences and intolerance, exclusion from representation, geographical and political factors, 
poverty, inequitable access to health, education and other resources that may cause discontent and dissonance where one party feels unfairly or unequally treated. Due to poor governance these have caused serious cracks, tribal divisions, suspicion and hatred in many African societies. Mahmood Mamdani quoted by Ligaga (2009) traces the historical origin of ethnicity in Africa to the colonial rule. According to him, the colonial administration constructed ethnicity by dividing Africans into tribes for ease of rule. They adopted a method whereby they put the Africans under the control of chiefs they appointed from among respected tribesmen and these reported directly to the colonial government. These chiefs and other colonial leaders were very powerful and had certain privileges over their subjects in order to serve the colonial government faithfully (Ndlvou-Gatsheni, 2011). In this regime, differentiation and inequalities in the distribution of privileges and power emerged among individuals and between clans and tribes, culminating into political tribalism

According to John Lonsdale as presented by Ligaga, political tribalism allows those in power to manipulate resources such that they are able to mobilize those of certain ethnic communities and 
especially their own to rally behind them in their quest for power in return for a reward or certain favours. This brings about division and disunity among tribes and societies. This is the kind of politics that is predominant in most African countries today. They are ravaged by the politics of form of oppressive supremacy, imposition of values, unequal distribution of resources and the suppression of the views and opinions of others. Such regimes are insensitive and oblivious to the horrifying and oppressive effects of lack of peace, and the presence of war, conflicts, militant attacks and disruptions of pacific situations.

Peace is the ultimate state for all human societies and since disruption and war, which are a creation of humankind, begin with a thought in the minds of people, it is in the minds of people that defense of peace must be constructed. Education therefore, can be used to promote this favoured state. Peace education should be taught in schools where the youth in their most impressionable age are in the hope that they will contribute to a more peaceful future society. This education should incorporate disarmament education, environmental education, human rights education and international relations education (Bajaj et.al 2009). It 
should deal with conflicts arising from injustice, exploitations and violation of human rights as well as from disagreement and war situations. Education generally should create a culture of peace, and facilitate the construction of a non-violent and just society that is necessary or essential for survival. Its main objective should be to sensitize youth on global problems and teach them how to play a positive and effective role in addressing and minimizing conflict. Targeting the youth to impart this education is important as they grow with these lessons imprinted in their minds and as adults make conscious peace choices.

A well planned and administered peace education can therefore usher in a culture of tranquility, which once acquired and internalized by all, would help minimize and eradicate social ills like poverty, exploitation, oppression, violence and war, which are ailing many societies in the world today. Peace education needs to be holistic, participatory and inclusive, focusing on human rights, democracy, international and intercultural tolerance and understanding of cultural, religious and linguistic diversities (Bhagabati, 2009). Such education would be one, which shuns individualism and incorporates the value of communal relationships that 
African traditional education strongly cherished and taught, and one, which values and respects individuals, observing that peaceful coexistence can only be achieved if respect of individuals and collective rights are observed.

According to Bhargabati, (2009) cohesion and tolerance can be achieved if human rights education is integrated in the curriculum of various school subjects and educational materials and especially school textbooks. It should be imparted through civic education, religious and moral education, as well as gender studies. In addition to the theoretical studies, learners should also have hands on practice in the affairs of the family, society, state at the national level. This would promote the spirit of community responsibility.

Africans had a functional community-based risk management mechanism that made them better prepared, safer, and more resilient in face of disasters. African traditional education valued community service, unity and solidarity. The policy of African can be summed up as 'one for all and all for one'. Mekeda (1999) quotes Akbar who observed that 'the unity of the African cosmos is like a spider Webb: its least element cannot be touched without 
making the whole vibrate'. This gives emphasis to the unity of the Africans and the value they placed on the individual as a part of the whole. It also spells out the willingness of the community to step in to protect the individual who makes it complete.

Individual calamity was unknown in traditional Africa. The whole community assisted and shouldered individuals from loss and gave resilience to the community from misfortune. This aspect can be replicated in education today with the youth being encouraged to give service to others without expecting anything in return to stamp out the growing culture in the modern world today whereby people expect a "tip" or "kitu kidogo" as it is known in Kenya which translates to "something small” or token as a form of appreciation, usually monetary, for every good deed they offer. In Kenya, the National Youth Service pre-university programme, which was a service-based training of the 80 's for all youth waiting to join the national universities, can be re-introduced to foster a sense of national service and to build patriotism. It will also encourage a sense of volunteerism and community service. Some universities in Kenya, such as the United States International University of Africa and Strathmore University endeavour to promote 
community awareness and the value of service through their community work programme whereby every student is required to give community service for at least a semester as a precondition for graduation. Some schools in Kenya, such as the Starehe Boys' Centre and School and Kianda Girls' School, also encourage voluntary service where their students give community service in hospitals and other areas of need.

In Ghana, community work is enhanced through the engagement of the youth in National Service Programme, where they serve the nation for a year before employment. This culture of volunteer service instills the value of service without discrimination and without seeking reward (Anzagra et.al. 2013). If it is internalized as a way of life as it was in traditional Africa, it would inculcate the virtue of humaneness and cultivate a sense of social responsibility, care and concern for social progress and wellbeing among the youth, thus giving credence to the adage that "together we stand, divided we fall". This paper recommends that other universities and learning institutions in Kenya adopt community work programmes, so that, communal work for the benefit of all becomes the norm, with such service being readily and freely given as was 
the case in traditional Africa. The pre- university national service can also be re-introduced and tailored to inculcate the virtue of service to others and volunteerism.

UNESCO (1996) in 'Learning-The Treasure Within' observes that education is a necessary utopia, and is crucial to confront future challenges, and to attain the ideals of peace, freedom and social justice. This report highlights four pillars of learning namely, learning to know, to do, to live together and to be. The third pillar, learning to live together, provides an enabling environment for the actualization of the other pillars and underscores the ingredients of cohesive living as developing an understanding of other people, appreciation of interdependence and learning to manage conflict. Its fundamental objective is the need to discover others and to work towards a common objective. In other words, it calls for community unity whereby all think together, work together to achieve together, and for each other, devoid of competition.

Peace education for African countries can integrate aspects of African traditional education that emphasize the value of human dignity, consideration, understanding and a sense of community 
belonging as epitomized in the Ubuntu philosophy. Within the curriculum, peace education can be housed to promote social inclusion, inclusion of marginalized groups, gender equality and the endorsement of values that honour individual rights, respect, tolerance and appreciation of diversity, respect for the environment and the promotion of values that relate to global responsibility and conscientiousness. This education should provide a greater understanding of the roots of conflict while offering suggestions for removal of social barriers, enhancing equality of gender, understanding and harmonious living in the present world (UN 2013).

This education could incorporate some of the less stern and extreme tenets of Pan Africanism, an ideology and movement that promote the solidarity of Africans worldwide. Kwame Nkrumah is one of the proponents of Pan Africanism, which views unity as key to economic, social and political progress, and argues that the fate of all Africans and African countries is intertwined (Cragg,2008). This ideology believes that the issues of one African state affect all the other states as they are all one, with a common history and a common destiny. 
It endorses solidarity for self-reliance and hence for independence and freedom from exploitation. In addition, the values carried in the different political philosophies and ideologies of the different countries which promote unity, peace and solidarity can be incorporated in this education. For instance, the values carried in the spirit of harambee in Kenya, which translates to "Let's pull together", the Tanzanian "Ujamaa" which means unity and family -hood, or the Zambian age-old slogan, "one Zambia, one Nation" can be incorporated in the peace education curriculum.

In the African set up, poverty was unknown. Poverty could only befall a whole community through a calamity such as a wide spread drought.

The community cushioned its members from want and need such that if an individual suffered a misfortune, the whole community went to his/her aid, a community based risk management mechanism. When a task such as planting, harvesting, building needed to be done, the whole community turned up with supplies, tools and implements, to offer service which may be labour, food, care for the children by the aged while the parents worked, singing and dancing to make working more pleas- 
urable and productive until the task was completed. Among the Akamba of Kenya, this pulling together is referred to as Mwethia. Formal education should promote a curriculum that encourages a greater understanding of the roots of conflict and how it can be prevented by sharing and preserving available resources.

Extra-curricular activities in schools should aim at peace-building by involving students in activities that promote tolerance and unity such as community outreach programmes and other community based activities that bring different people together to work as one team. Team building activities should be encouraged as they bring people together to work and solve common problems collectively. Highlighting the importance of team building in affecting the humanness of individuals, Creely Daniel (n.d.) observes that:

Over thirty years of research has proven these group activities develop a bond among students which breaks down social, sexual, racial and cultural barriers. Students develop a "code of responsibility" and a value system that carries over beyond the walls of the classroom. Students do not become 'harder' by their experiences. Quite the contrary, they become 'softer'. They become more 
caring human beings who demonstrate compassion for others (para 7).

These values promote tolerance and acceptance and therefore cohesiveness and unity, all prerequisites to harmonious living, the desired goal of peace education.

Beliefs, cultures, values and practices of different people should be incorporated in the school programme and curriculum in subjects such as History, Geography, and in clubs and other cocurricular activities to build tolerance and appreciation of other people and cultures. This can be enhanced by cultural exchange programmes which can take a simple form of learning different cultural dances in school clubs or more complex forms such as cultural exchange visits and trips. An exchange and interaction of culture can eliminate differences and bring acceptance and equality by reducing the creation of a different "other" class of people or as Ligaga (2009) puts it:

...the 'other' is seen...as different and inferior to 'us' (and) "our" culture is seen as superior and pervasive and the 'other' must be measured against it, where they either fail, or become exorcized (75) 
School mottos can be coined to carry peace bearing and unifying messages. These are a brief statement, sentence, phrase or axiom adopted by a school to express an attitude, principle, goal, or ideal as a guide to one's conduct and character (Free Dictionary, n.d.). They are used to drive home desired messages or core values and virtues and to instill into the students the values espoused by the school. These should be repeated often in order to internalize them since what is internalized is practiced and therefore learnt. A school motto can be a source of motivation, identity and inspiration. It is a constant reminder of a vision and value and therefore can be very useful in passing peace messages to the youth. School mottos fit in the traditional education methods where proverbs and sayings were used to communicate societal values and teachings.

Peace can also be promoted through the use of information technology (IT). Today, IT is one of the most powerful tools of communication. It has been used to bring political change as in the case of Egypt where it was applied to resist oppressive rule in 2011-2012. It has also been used to mobilize youth for political campaigns to support certain political parties and candidates as it happened in 
Kenya during the presidential and parliamentary elections of 2007 and 2013.

Information technology can be used to promote peace messages, to carry out peace campaigns or give peace education using social media networks such as Facebook and Twitter as was the case in Kenya during the 2012-2013 campaigns and elections. These social networks bring together networks of friends and friends of friends from different backgrounds, race and creed to form powerful unifying channels for peace promotion. They play a similar role as music and dance in traditional Africa, which were uniting avenues, used to pass messages, lessons and values. Traditionally, dance was a primary expression of human culture that was used for communication, community building, social interaction, healing, and religious ceremonies throughout the world. Indeed dance, like music, is a global language, transcending barriers and differences and bringing different cultures together (World Peace through Technology Organization, WPTTO, n.d.).

IT provides the ability to create and distribute music, an important tool for building world peace worldwide. It has facilitated in informing 
people on different cultures and practices, and in the sharing and experiencing of different cultures such that people find commonness and understanding and realize that no matter what part of the world they come from they are all basically the same human beings. Music crosses all bridges, borders, and time zones and transcends all ideologies, politics, religions, languages, cultures, and wealth. It is oblivious to race, gender, age, and appearance and acts as a bonding sap binding different people with different cultures together (WPTTO, n.d.).

Art and theatre, like music, song, dance and other cultural carnivals, can be powerful tools for peace promotion. Art and theatre involve the use of live performances to present the experiences of real or imagined events before a live audience through a combination of gestures, speech, songs, music or dance. They can take on a wide range of forms, including narrative dialogue, opera, ballet and mime. Theatre can also be viewed as a means of expressing ideas, views and situations taking place in the present, sometimes in different places, but connecting us to other times and places through the use of characterization, design, technology and actors, while providing insights into the issues affecting societies, their relationships and encounters. On 
the whole, theatre is a dynamic and vibrant form of art, which is constantly changing to include current affairs, new media and trends in society (Erven, 2001). Since time immemorial, theatre has been used by societies to foster healthy relationships, give important lessons and teachings and to unify people within the society. It still remains a vital tool for passing important messages and can be used to enact the value of peace, the vices of war and conflict and the avenues of peaceful conflict resolution.

The value of theatre arts cannot be underestimated. First, it provides entertainment which is not only entirely limited to comedy or causing laughter, but being able to capture the attention of the audience. This is important as it is easy to pass a message to an attentive audience. Secondly theatre is also a medium of unity in that it brings a varied audience together and communities can act together thus breaking down exclusion of marginalized groups within a society or nation.

Theatre is also able to portray life both inside and outside the community or society of the audience. Hence, it can be used to promote peace or other intended messages by transporting the audi- 
ence to another society, place or intended situation or to enact the undesirable situation showing its evils and therefore affect the audience to desire to change (Smith S., Webb, E 2011). One of the most important functions of theatre is that it inspires its viewers by providing them with thought-provoking ideas and questions. The audience should be drawn into the play, to the extent of constantly asking themselves, what they would do if they were in that situation. This is very important in the promotion of peace as it challenges the viewers to be proactive in the quest to promote and maintain peace, and in finding peaceful solutions to issues affecting their lives. The spectators are encouraged to critically think and ask questions about themselves and the society they live in and assess their role in changing it. Theatre can also provide answers to these questions and excite its viewers to be players in the promotion of peace. Hence, theatre can be used to bring about desired change.

Language in African indigenous education was a crucial tool in promoting culture and transmitting values held dear by the society. Legends, poems, songs, dance, lullabies, stories, proverbs, sayings and tongue twisters were used to give intellectual education, teach oral literature and tribal 
history, language, test wit, mastery of language and memory. School clubs provide essential avenues of promoting peace by bringing students with a common agenda together and exposing them to different situations, cultural practices, beliefs and values, and therefore promoting understanding and tolerance of different cultures.

Debate and dancing clubs can also be important avenues to promote cultural tolerance, which in turn promote peaceful coexistence. Exposing the youth to different cultures and ideals of other communities and people, makes them more understanding and tolerant to diversity, such that they learn to embrace and respect differences and diversity; a prerequisite for peaceful living. Efforts to use these avenues for peace promotion in Kenya include the Kenya Music and Drama Festivals and the Science Congress among other school activities, which are held annually.

\section{Conclusion}

The concept of oneness, unity and community, is important for the promotion of peace. As Desmond Tutu notes, people are interrelated and interconnected and cannot exist in isolation or seg- 
regated or be human by themselves. He observes that people often think of themselves far too frequently as individuals, separated from others, whereas they are in actual fact connected and what they do affects the whole world. When they do well, it is for the benefit of the whole humanity. He sees Ubuntu as the acceptance of others as parts of the sum total of each of individual (Tutu n.d.). Similarly, a common saying observes that no man is an island or cannot be self-sufficient. People need each other, which means they must foster harmonious living in order to be there for each other. Samkange, in Ubuntu Philosophy (n.d) puts this succinctly in his analysis of the Zimbabwean concept of the Ubuntu philosophy, which in the Shona language is known as Unhu. He asserts, "To be human is to affirm one's humanity by recognizing the humanity of others and on that basis, establish respectful human relations with them", a view that holds that an individual's identity is in the society in which they belong. Hence, peace in every social setting is paramount.

Hence the welfare and advancement of a country is wholly dependent on the unity of its people and their desire and resolve to work together for the common good. Acting together as a commu- 
nity is the key to development and the creation of a peaceful, cohesive and progressive society. In cognizance of this fact, Theodore Roosevelt, former president of the United States of America aptly noted in 1903 that:

The welfare of each of us is dependent fundamentally upon the welfare of all of us, and therefore in public life that man is the best representative of each of us who seeks to do good to each by doing good to all; in other words, whose endeavor it is not to represent any special class and promote merely that class's selfish interests, but to represent all true and honest men of all sections and all classes and to work for their interests by working for our common country (para 5) 


\section{References}

African Cultural Values (n.d.) Retrieved on 29/10/12 from www.emeka.at/african_cultural_values.pdf

Amollo, A. M. (2002). From playing to learning to changetheatre in conflict transformation and peace building. Nairobi: Kenya Amani Peoples Theatre.

Amollo, A. M., \& Ayindo, B. T. (2002). Reflections on impact assessment indicators: Issues in arts and peace building. Nairobi: Kenya Amani Peoples Theatre.

Anzagra, S. \& Adjei S. A. (2013) Drawing the Best from National Service in Ghana: Issues for a Rethink. Retrieved on $1 / 11 / 2012$ from

Bajaj, M. \& Chiu, B. (2009). Education for Sustainable Development as Peace Education, peace and Change Peace History Society and Peace and Justice Studies Association Vol. 34, No.4, 442-446.

Bhagabati, N. (2006). Peace education for sustainable development", The Green Changemakers: Collections of Resources for Sustainable and Green Living, excerpt from the paper presented at $10^{\text {th }}$ APEID UNESCO Conference held at Bangkok $6^{\text {th }} 8^{\text {th }}$ December 2006. Retrieved on 31/10/2012 from http://greenchangemakers.blogspot.com/2009/06/peaceeducation-for-sustainable.html 
Bogonko, S. N. (1992). A History of Modern Education in Kenya, (1895-1991). Nairobi: Kenya Litho Limited

Conforini, C. C. (2006). Gultang, Violence, and Gender, the Case of Peace Studies /Feminism Alliance, Peace and Change. A Journal of Peace Research Vol. 31 No. 3 July, 334-336. Retrieved on 22/11/2012 from http://www2.kobe-u.ac.jp/ alexroni/IPD\%202012/2012_2/Galtung,\% 20Violence\%20and\%20Gender\%20\% 28Confortini\%29.pdf

Cragg, K. (2008) Organizing African Unity: a PanAfrican Project: A Comparison of the Organization of African Unity And the African Union Unpublished BA thesis Wesleyan University Middletown, Connecticut

Creely, D. P. Jr. (n.d.) Can Teambuilding and Challenge Programs Transform Education? TEAM - Physical Ed. Dept. Northeastern Ill. University St. Louis Chicago, Illinois. Retrieved on 2/11/12 from http://www.neiu.edu/ tstirlin/peace/ spectop4.htm

Ejizu, C. I. (n.d.) African Traditional Religions and the Promotion of Community-Living in Africa. Retrieved on 1/11/2012 from http:// www.afrikaworld.net/afrel/community. Html 
Erven, V. (2001). Community Theatre: Global Perspectives-What is the function of theatre? London: Rutledge. Retrieved on 21/11/2012 from (http:// www.123helpme.com/view.asp?id=97713)

Free Dictionary (n.d.). Retrieved on 23/10/2012 from http://www.thefreedictionary.com/motto

Grewal, B. S. (2003). Johan Galtung - Positive and negative peace. Retrieved 0n 12/11/2012 from http:// upeaceap.org/hando_upfiles/FCPC_RM_06_1.pdf

Ligaga, D., (2009) Ethnic Stereotypes and the ideological manifestations of ethnicity in Kenyan cyber communities. Africa Insight; Development Through Knowledge Vol. 39(1), 72-75.

Lotte, H. (2011). "Promoting peace through dialogue: facilitating cultural exchange visits in Kenya", Ferguson Centre for African and Asian Studies Working Paper No. 1 February 2011 Retrieved on 18/11/2012 from http://www.open.ac.uk/Arts/ ferguson-centre/working-papers/working-paper1.pdf

Mbiti, J. (1989). African religions and philosophy, (2nd ed.). Oxford: Heinemann.

Mekada, J. G. (1999). The African centred worldview: Developing a paradigm for social work. British Journal of Social Work 29(2), 256-259. Retrieved 
on 20/11/2012 from http://

bjsw.oxfordjournals.org/content/29/2/251.full.pdf

Menkiti, I. A. (n.d.). Person and community in African traditional thought. Retrieved on 20/11/2012 from http://health.cat/open.php?url=http:// courseweb.stthomas.edu/sjlaumakis/Reading\% 203-AFRICAN\%20VIEW.pdf

Mosha, S. (2000). The Heartbeat of Indigenous Knowledge: A study of the Chagga Education System. New York: Routledge

Ndlvou-Gatsheni, S. J. (February 2011). The logic of violence in Africa. Ferguson Centre for African and Asian Studies Working Paper No. 2, 1-

13.Retrieved on 20/11/2012 from http:// www.open.ac.uk/Arts/ferguson-centre/workingpapers/working-paper-2.pdf

Ocitti, J. P. (1973). African indigenous education as practiced by the Acholi of Uganda. Nairobi: East Africa Literature Bureau.

Ojomo, P. A. (December 2010). An African understanding of environmental ethics thought and practice. A Journal of the Philosophical Association of Kenya (PAK) New Series 2(2).

Okolo, C. B. (n.d). Urbanization and African Traditional Values. Retrieved on 21/11/2012 from http:// www.crvp.org/book/Series02/II-3/chapter_v.html 
Okoro, K. (2010). African traditional education: A viable alternative for peace in modern Africa. Journal of Alternative Perspectives in the Social Science 2 (1). 136-158. Retrieved on 21/11/2012 from http:// www.japss.org/upload/7._Okoro\%5B1\%5D.pdf

Otiende, J. E., Wamahiu, S.P., Karugu, A.M. (1992.) Education and development in Kenya: A historical perspective. Nairobi: Oxford University Press

Roosevelt, T. XXXVI. (1903). A Square Deal, Address to the New York State Agricultural Association, Syracuse NY Sept 1903. Retrieved 21/11/2012 from http://www.presidency.ucsb.edu/ws/ index.php?pid=24504.

Sifuna D., Chege F., Oanda, I (Eds.), (2006). Themes in the study of foundations of education (pp. 60-65), Nairobi: Jomo Kenyatta Foundations

Smith S., Webb, E. (2011). Acting Out of Conflict: Using Participatory Theater as a Tool of Peacebuilding in Rwanda. Africa. Peace and Conflict Journal Vol. 4 No. 2, 67-78. http://www.apcj.upeace.org/ issues/APCJ_Vol4_Num2_WebOnly.pdf

Squidoo (n.d) Wisdom from Africa: African Proverbs and Quotes (n.d). Retrieved 29/10/2012 from http:// www.squidoo.com/African-quotes-proverbs-andsayings

Tutu, D. (n.d). Desmond Tutu explains Ubuntu. I am 
because we are (Retrieved on 2/11/2012 from

http www.ikbenomdatwijzijn.info/index.php

Ubuntu Philosophy (n.d.) Retrieved on 21/11/2012 from

http://en.wikipedia.org/wiki/Ubuntu_\%

28philosophy\%29

UN Sustainable Development Knowledge Platform (2013)

Future we Want: Outcome Document, Retrieved

on $1 / 11 / 2012$ from http://

sustainabledevelopment.un.org/

futurewewant.html

UNESCO, (1996). Learning: The treasure within. Report to UNESCO of the International Commission on Education for the Twenty First Century. Retrieved on 18/10/2012 from http://

unesdoc.unesco.org/ images/0010/001095/109590eo.pdf

Wikipedia (n.d.) Theatre retrieved on 18/11/2012 from http://en.wikipedia.org/wiki/Theatre World Peace Through Technology Organization retrieved on 1/11/2012 from http://peacetour.org/ 